\title{
Jacques Ribard, Symbolisme et christianisme dans la littérature médiévale
}

\section{Maria Colombo Timelli}

\section{(2) OpenEdition}

10 Journals

\section{Édition électronique}

URL : https://journals.openedition.org/studifrancesi/40387

DOI : $10.4000 /$ studifrancesi.40387

ISSN : 2427-5856

Éditeur

Rosenberg \& Sellier

\section{Édition imprimée}

Date de publication : 1 juillet 2004

Pagination : 164-165

ISSN : 0039-2944

\section{Référence électronique}

Maria Colombo Timelli, « Jacques Ribard, Symbolisme et christianisme dans la littérature médiévale »,

Studi Francesi [En ligne], 142 (XLVIII | I) | 2004, mis en ligne le 30 novembre 2015, consulté le 09 septembre 2021. URL : http://journals.openedition.org/studifrancesi/40387 ; DOI : https://doi.org/ 10.4000/studifrancesi.40387

Ce document a été généré automatiquement le 9 septembre 2021.

\section{(c)}

Studi Francesi è distribuita con Licenza Creative Commons Attribuzione - Non commerciale - Non opere derivate 4.0 Internazionale. 


\title{
Jacques Ribard, Symbolisme et christianisme dans la littérature médiévale
}

\author{
Maria Colombo Timelli
}

\section{RÉFÉRENCE}

JACQUES RIBARD, Symbolisme et christianisme dans la littérature médiévale, Paris, Honoré Champion, 2001 («Essais sur le Moyen Age», 25), 308 pp.

1 La quatrième et dernière section de ce recueil d'articles est consacrée aux Poésies de François Villon. Un premier essai (Le «Lais» de François Villon et sa thématique symbolique, pp. 277-285; paru dans les Mélanges P. Demarolle, Paris, 1998) propose une approche symbolique du Lais; quelques oppositions thématiques sont d'abord mises en relief: la «morte saison» et la chaleur du feu, le froid hivernal et l'appétit pour ce qui est gras et onctueux, la «prison» et la fuite, le départ, le voyage. Au-delà de ces motifs à l'apparence banale et concrète, J. R. lit l'opposition fondamentale entre ce qui lie l'homme aux choses de ce monde et l'appel irrépressible à une nouvelle vie, annoncée par le Noël du v. 10.

2 Une deuxième contribution (Le didactisme dans l'œuvre de François Villon, pp. 287-295; publié dans les Mélanges $P$. Suard, Lille, 1999) vise à mettre en relief un aspect normalement négligé de l'œuvre de Villon, son didactisme justement. C'est pourtant Villon lui-même qui déclare son appartenance au monde des Ecoles, se revendique comme clerc, et affronte certains sujets de réflexion philosophique chers au Moyen Age, tels le débat sur Fortune ou le problème de la Connaissance. François Villon ne néglige pas la pratique du «débat» et de la «dispute», et, s'il parle volontiers de luimême, c'est aussi et d'abord aux autres qu'il s'adresse.

3 L'«Epître à Marie d'Orléans» et la «Louenge à la court»: un double registre de langage chez Villon (pp. 297-305; paru dans les Mélange J. Subrenat, Paris, 2000) propose la lecture de deux 
poèmes peu appréciés par la critique, que J. R. invite à relire en reconnaissant la présence de deux registres de langage, le profane et le religieux, en relevant les parallélismes dans l'expression, et surtout en dépassant le plan concret et matériel pour atteindre ce qui intéresse vraiment le poète: la seule réalité qui compte est d'ordre entièrement spirituel. 